\title{
The Influence of Community Characteristics towards Telecentres Success
}

\author{
Nor Iadah Yusop, Shafiz Affendi Mohd Yusof, Zahurin Mat Aji, Huda Hj. Ibrahim, Mohd. Khairudin Kasiran, \\ Zulkhairi Md. Dahalin, Nor Farzana Abdul Ghani, Rafidah Abd. Razak, Syahida Hassan \\ UUM College of Arts and Sciences, Information Technology Building \\ Universiti Utara Malaysia, 06010 UUM Sintok, Kedah, Malaysia \\ Tel: 60-4-928-4701 \\ E-mail:\{noriadah|shafiz|zahurin|huda753|mkasiran|zul|farzana|rafidah|syahida\}@uum.edu.my
}

Abdul Razak Rahmat (Corresponding author)

UUM College of Arts and Sciences, Information Technology Building

Universiti Utara Malaysia, 06010 UUM Sintok, Kedah, Malaysia

Tel: 60-1-2428-7153 E-mail : arazak@uum.edu.my

\begin{abstract}
Telecentres are physical spaces that provide public access to information and communication technology particularly the Internet for educational, personal, social, and economic development. This paper will closely look into the characteristics of the community that influence the success of telecentres. Although there are a number of influential factors in regards to community characteristics, the emphasis will be on groups and networks factor. Survey was conducted to collect data from users regarding their use of telecentres. In the questionnaire, apart from the users' profiles, items related to the groups and networks were also included. Sampling was done based on a population comprising of telecentres implemented by state governments, non-governmental organizations, and private sectors. The findings suggest that there are some indications showing certain self belonging, as consequences to the usages of telecentres, to a group and establishing networks which can contribute to the success of telecentres.
\end{abstract}

Keywords: Telecentres, E-communities, Social Capital, Groups Networks

\section{Introduction}

Telecentre (TC) provides various information and communication technology (ICT) services, such as access to the Internet, computers and software, electronic commerce applications, and other public information services with the aim of achieving various development objectives especially the Internet for educational, personal, social, and economic development (Riley \& Gomez, 2001). TCs are set up to improve computer education and empower rural communities to access and utilize information to improve their economic and social well-being (Harris et al., 2007). In addition, the local community can used the centre for various activities such as social gathering activities, student leaning activities and interactions.

A range of important issues is linked to the operation and success of TCs. Besides sustainability, government policy, information and community technology, business planning, and TC objectives, Roman and Cole (2002) have included (i) community partnerships and participation, and (ii) community relevance as other important dimensions in creating a successful TC. There must be participating communities in the planning and managing activities related to TCs project. This is inline with Rao (2008) study that stressed on the importance of community participation for TC sustainability. In regards to community relevance, TCs need to be relevant to their clientele, especially in the contents provided to communities. Much of the information available via electronic networks, for example through websites, portals may not meet communities' needs for local information on agriculture, socio economy, and health and nearby markets. Irrelevant contents and materials would be useless to communities if most of them are not delivered in national or local language. This is inline with Roman and Cole (2002) that stated application content should be made and tailored to the community needs. In addition, in the Malaysian context, Norizan (2005) also mentioned that technology should also be made available to all due to its cheaper price, subsidies and financial support given by telecommunications companies. Furthermore, for TC sustainability, she stated that the TC communities must be empowered to ensure the communities benefit from the TC establishment (Norizan, 2009).

There has not been much work that have examined TCs success from the sociological perspectives using the 
social capital theory. The objective for this research was to find out the positive characteristics of communities as indicators for TCs to succeed. In order to understand and answer the research question regarding the characteristics of communities, the Social Capital Theory was used. The main purpose of using this theory is to examine the sociological aspects of the members' in a community. This paper closely looks into the characteristics of the community that influence the success of TCs. Although there are a number of influential factors in regards to community characteristics, the emphasis will be on groups and networks factor.

\section{Literature review}

\subsection{Community}

The term community originated from the Latin word communis. Fernback and Thompson (1995) suggest that communis can be formed by pairing (i) cum refers to together and munus refers to obligation, or (ii) cum meaning together and unus meaning one. Community can be referred to as a group in which individuals participation is based on an obligation to one another or as a group in which individuals participate to be one in purpose (Reid, n.d.). Therefore, a sustained social interaction, shared attributes and values, and a delineated geographical space need to be in place for the community to function effectively and efficiently (Lawrence, 1995). However, management scholar suggests that it is membership rules not the geographical boundaries, which help sustain the community (Lawrence, 1995).

The community to the ordinary inhabitant is where he lives, and probably works. It is associated with a place and a name in his thought (Nelson et al., 1960). They further add that community is where one goes to shop, to attend a show, to meet friends, or simply to loaf. The common-sense concept of community is that it involves an area, people, and the relationships among people (structure). The elements of structure in a community consist of groups, formal organizations, and institutions, division of labor, values, social differentiation, and functions. Therefore, community may be formally defined as (Nelson et al., 1960):

..the structuring of elements and dimensions to solve problems which must be or can be solved within the local area.

\subsection{Social capital theory}

Recently, the understanding of social capital is becoming critical and significant apart from the financial, human, intellectual, and other capitals in today's communities. Social capital is the social fabric or glue that holds communities and other social networks together. The basic premise here is the interaction that enables people to build communities, to commit themselves to each other, and to knit the social fabric (Smith, 2001). Those concerned with social capital have examined the density of social networks that people are involved in; the extent to which they are engaged with others in informal social activities; and their membership of groups and associations.

It is important to note that social capital is becoming a core concept in business, political science, healthcare, and sociology. Social capital is a common framework for understanding the depth of a community's social connectedness. It refers to features of social organization such as networks, norms, and social trust that facilitate coordination and cooperation for mutual benefit (Putnam, 1995). The World Bank refers social capital to the institutions, relationships, and norms that shape the quality and quantity of a society's social interactions (The World Bank, 1999). Increasing evidence shows that social cohesion is critical for societies to prosper economically and for development to be sustainable. Social capital is not just the sum of the institutions which underpin a society - it is the glue that holds them together (The World Bank, 1999). Another view of social capital is that social capital consists of the stock of active connections among people: the trust, mutual understanding, and shared values and behaviors that bind the members of human networks and communities and make cooperative action possible (Cohen \& Prusak, 2001). Hence, we have adapted the Social Capital Theory (Grootaert et al., 2000) to measure the characteristics of communities. The selected variables used in the survey were:

a) Groups and Networks. The questions here consider the nature and extent of one's participation in various types of social organizations and informal networks, and the range of contributions that one gives and receives from them. It also considers the diversity of the membership in group, how its leadership is selected, and how one's involvement has changed over time.

b) Trust and Solidarity. This category seeks to procure data on trust towards neighbors, key service providers, and strangers, and how these perceptions have changed over time.

c) Collective Action and Cooperation. This category explores whether and how household members have worked with others in their community on joint projects and/or in response to a crisis. It also considers the 
consequences of violating community expectations regarding participation.

d) Social Cohesion and Inclusion. Questions in this category seek to identify the nature and extent of the various forms that can lead to conflict, togetherness, and everyday forms of social interaction are also considered.

e) Empowerment and Political Action. The questions in this section explore members' sense of happiness, personal efficacy, and capacity to influence both local events and political outcomes.

The survey instrument attempts to reflects the group membership ("structural") and subjective perceptions of trust and norms ("cognitive"), the main ways in which social capital operates (collective action and cooperation), and major areas of application or outcomes (social cohesion and inclusion, and empowerment and political action) (Grootaert et al., 2000).

\section{Methodology}

The base sampling for this research is TCs establishment in Malaysia. Sampling was done based on a population comprising of TCs implemented by state governments, non-governmental organizations (NGOs), and private sectors. The population list is obtained through Internet searches, from the K-Economy Section, Economics Planning Unit (EPU) of the Prime Minister's Department, state government offices, as well as telephone calls to NGOs and private sector TCs. A total of 132 TCs have been identified for this study. These TCs are part of the 1945 TCs in EPU list in addition to a few TCs which are not. The data collection sites were divided into four regions: Northern Region (Perlis, Kedah, Penang, and Perak), Central Region (Selangor, Wilayah Persekutuan, and Negeri Sembilan), Southern Region (Malacca and Johore), and Eastern Region (Kelantan, Terengganu, and Pahang). Based on the sampling used, we distributed questionnaires to the TCs' users through mail or hand-delivered while visiting the TCs. Table I shows the distribution of questionnaire according to the regions and method of distributions.

Survey was conducted to collect data from users regarding their use of TCs. Based on the total of 132 TCs, 1314 questionnaires were distributed with response rate of $41.1 \%$. In the questionnaire, apart from the users' profiles, items related to the groups and networks were also included. The responses were captured based on five-point Likert scale. The characteristics of a community that contribute to the success of a TC is assessed based on five main factors namely (1) Groups and Networks, (2) Trust and Solidarity, (3) Collective action and cooperation, (4) Social Cohesion and Inclusion, and (5) Empowerment and Political Action.

In regards to groups and networks, there are five questions that respondents need to answer. The first is regarding the importance of them belonging to a group or association. The second question is related to the benefits gained by belonging to a group. The third question tries to capture if the leaders are chosen democratically. The fourth question inquires whether the chosen leaders are effective. Finally, the respondents were asked regarding the public acceptance of their group.

\section{Findings}

In terms of the demographic profile, majority of the respondents (93.4\%) aged below 40 years old with overall is fairly distributed between male $48.3 \%$ and female $51.7 \%(n=540)$. Most of the respondents' education levels are moderately low whereby $72.2 \%$ is up to Form 5 (upper secondary school). Almost $70.0 \%$ earn less than RM1500 a month with $21.8 \%$ is comprised of those who fall under the poverty level.

Regarding IT facilities ownership, $52.8 \%$ of the respondents own a computer at home. Out of this, almost $41.0 \%$ have Internet connection, either through dial-up (70.0\%) or Broadband (54.3\%). Pertaining to the usage of TCs, majority of the respondents indicate that they have experienced using the TCs $(79.8 \%)$. In this study, a successful TC is identified through the length of TC usage (in this case more than seven months) by the users. This is to reflect the duration for a TC to be able to retain recurring users. It has been discovered that, based on this factor, three TCs, namely the E-Desa (state government), TMPintar (private), and Pusat Bestari (state government) falls under this category with the percentage of 66.0, 100.0, and 64.3 respectively. Then the respondents from these TCs have been chosen to rate the importance of groups and networks factor through five statements listed below:

i. $\quad$ Being a member of an association or group in my community is important to me.

ii. I gain a lot of benefits by belonging to a group or association.

iii. Leaders are chosen based on democratic process.

iv. As an overall, the group leader is effective.

v. The group that I belong is well recognized and supported by the community.

These questions are adopted from well-tested social capital theory. The findings are as tabulated in Table II. 
More than $90.0 \%$ of the respondents agreed that it is important to belong to a group or an association. Their views are supported by their responses on the second question where they $(90.3 \%)$ believe that they will get benefit from being a member of a group or an association. In order to be a member of any group or association, $87.1 \%$ of the respondents deem that the leader needs to be elected democratically. In addition, effective leadership of a group or association has also been identified (by $89.4 \%$ of respondents) to be one of the important aspects for a successful group or association. Finally, the respondents (89.3\%) feel that it is important for their group is being recognized and accepted by the general public. In general, the five questions have captured the essence of groups and networks factors. The findings suggest that, groups and networks factor is present in the communities surrounding the three successful TCs.

\section{Conclusion and recommendations}

The findings suggest there are indications that show belonging to a group and establishing networks contribute to the success of TCs. It has been found that, most TCs' users belong to a group or an association. Being so, they could use the TC as a platform to organize any group or associations activities. This would encourage members of the group or association to be familiarized with the facilities the TC offers, thereby creates awareness among them. Having networks of friends or peers, they would also help in creating the awareness by being attracted to the TCs. With having networks of friends, TC could offer discount and benefit to the person that brings his network of friends to use the TC. For example, if a person invites four of his friends to the TC, the management would offer the person ten minutes of free Internet usage per person recommended.

A high percentage of them also agreed that they could gain benefits by being in a group or association and leaders in the group are being chosen fairly. This would reflect the norms used in the group can be implemented in choosing appropriate leader to manage the TC. This kind of leaders would have the characteristics and the potential to influence the people from the group in particular and the community as a whole. This is important to the success of TC, especially in terms of its usage.

Most importantly, it was found that the feeling that their group is being accepted by the general public is significant to the success of the TCs. This creates the sense of belonging to the community, which in turns would help them to participate in the advancement of the TC's achievement. Activities that are planned and designed for such community would gain support and commitment from the surrounding community. As a result, the TCs will be more 'vivacious'.

\section{References}

Cohen, D. \& Prusak, L. (2001). In Good Company. How social capital makes organizations work, Boston, Ma.: Harvard Business School Press.

Economic Planning Unit (2007). Rangka kerja strategik kebangsaan bagi merapatkan jurang digital (NSF-BDD), presented at Bengkel Pusat Perkhidmatan dan Ilmu Komuniti Peringkat Negeri Pulau Pinang, 13 Jun 2007. [In Malay]

Fernback, J. \& Thompson, B. (1995). Virtual Communities: Abort, Retry, Failure?Available: http://www.well.com/user/hlr/texts/VCcivil.html, 1995. (February 10, 2009)

Grootaert, C., Deepa, N., Jones, V.N. \& Woolcock, M. (2000). Measuring social capital: An integrated questionnaire, World Bank Working Paper 18, World Bank, Social Development Department, Washington D.C.

Harris, R.W., Yogeesvaran, K. \& Lee, L.W. (2007). Telecentres for national e-inclusion in Malaysia, Economic Planning Unit of the Prime Minister's Office, Government of Malaysia, 2007.

Lawrence T.B. (1995). Power and resources in an organizational community, Academy of Management Best Papers Proceedings, 251-255.

Nelson, L., Ramsey, C.E. \& Verner, C. (1960). Community structure and change. New York: The Macmillan Co.

Norizan, A.R. (2005). An analysis of Malaysian e-community centers in bridging the digital divide, paper presented at the E-Malaysia Seminar, 6-7 December.

Norizan, A.R. (2009). Empowering the rural communities via the telecentres. European Journal of Social Sciences, 9 (3), 425-432.

Putnam R.D. (1995). Bowling alone: America's declining social capital, Journal of Democracy, 6, 65-78.

Rao, S.S. (2008). Social development in Indian rural communities: Adoption of telecentres. International Journal of Information Management, 28, 474-482.

Reid J.N. (2000). How people power brings sustainable benefits to communities, USDA Rural Development 
Office of Community Development, June. Available: http://www.rurdev.usda.gov/rbs/ezec/Pubs/commparticrept.pdf (February 6, 2009).

Riley, K. \& Gomez, R. (2001). Comparing approaches: Telecentre experiences in Asia and Latin America. Journal of Electronic Journal on Information Systems in Developing Countries, 4 (3), 1-17.

Roman, R. \& Colle, R.D. (2002). Themes and issues in telecentre sustainability. development informatics, Working Paper Series, Paper No. 10. Institute for Development Policy and Management, University of Manchester, Precinct Centre, Manchester, M13 9GH, UK.

Smith, M.K. (2001). Social capital. In The Encyclopedia of Informal Education, Available: http://www.infed.org/biblio/social_capital.htm (May 5, 2009).

The World Bank (1999). What is social capital? PovertyNet, Available: http://www.worldbank.org/poverty/scapital/whatsc.htm (April 21, 2009).

Table 1. Distribution of TCs and Questionnaire

\begin{tabular}{|l|l|l|l|l|}
\hline Region & Total TCs & TCs Visited & TCs via mail & No. of Questionnaire Distributed \\
\hline North & 44 & 4 & 40 & 453 \\
\hline Central & 33 & 6 & 27 & 311 \\
\hline South & 29 & 9 & 20 & 290 \\
\hline East & 26 & 8 & 18 & 260 \\
\hline Total & 132 & 27 & 105 & 1314 \\
\hline
\end{tabular}

Table 2. The importance of groups and networks factor

\begin{tabular}{|l|l|l|l|l|}
\hline Group \& Network Factors & $\begin{array}{l}\text { E-Desa (\%) } \\
\mathrm{n}=46\end{array}$ & $\begin{array}{l}\text { TM Pintar (\%) } \\
\mathrm{n}=20\end{array}$ & $\begin{array}{l}\text { Pusat Bestari (\%) } \\
\mathrm{n}=67\end{array}$ & $\begin{array}{l}\text { Overall } \\
(\mathrm{n}=134)\end{array}$ \\
\hline $\begin{array}{l}\text { Being in a } \\
\text { group/association }\end{array}$ & 100.0 & 86.6 & 90.2 \\
\hline $\begin{array}{l}\text { Benefiting from being a } \\
\text { member of a group/ } \\
\text { association }\end{array}$ & 91.8 & 100.0 & 81.1 & 90.3 \\
\hline $\begin{array}{l}\text { Democratically chosen } \\
\text { leader }\end{array}$ & 73.9 & 100.0 & 92.4 & 87.1 \\
\hline Effective leadership & 89.4 & 85.0 & 92.3 & 89.4 \\
\hline Acceptance by the public & 95.7 & 85.0 & 95.4 & 89.3 \\
\hline $\begin{array}{l}\text { Average Group \& } \\
\text { Networks Factor }\end{array}$ & 80.4 & 100.0 & 79.4 & 82.8 \\
\hline
\end{tabular}

